\title{
THE DYNAMICS OF MANAGING THE RISING UNEMPLOYMENT HURDLES IN NIGERIA: A FOCUS ON IMO STATE
}

Ebiziem, Jude Ebiziem, Ph.D

Department of Political Science

AlvanIkoku Federal College of Education, Owerri

E-mail: mbanoguesthouse@yahoo.com, +2348035077757

\author{
Ebere, Nnanyere Nwachukwu I. \\ Department of Public Administration \\ Federal Polytechnic Nekede, Owerri \\ E-mail: ebere_Onyike@yahoo.com, +2348036769168 \\ Okereke Chukwuemeka O. \\ Department of Political Science \\ AlvanIkoku Federal College of Education, Owerri \\ E-mail: chukwuemeka1@ gmail.com, +2348032938714 \\ Ekejiuba, Sylvia C. C \\ Department of History and International Studies \\ Imo State University, Owerri \\ E-mail: sylviaelegant@gmail.com, +2348182981327
}

\begin{abstract}
This study examines the causes and effects of unemployment in Nigeria with particular reference to Imo State. The National Bureau of Statistics (NBS) report on unemployment showed that the country unemployment rate increased to $27.1 \%$ in the second quarter of the year $\left(Q_{2} 2020\right)$ compared to $23.1 \%$ of the third quarter $\left(Q_{3} 2018\right)$. Imo State both in terms of unemployment and underemployment records $48.7 \%$ and $75 . s \%$ respectively. The report is worrisome as it poses threat to the State development, security and peaceful co-existence. The main objective is to look into the causes, effects and solution to unemployment problem. The study reviewed extant literature anchored on the theory of Neo-liberalism of Marxist. Also, historical and descriptive research design with secondary method as sources of its data collection were utilized, while content analysis was adopted. The result of the study reveals that unemployment is a multidimensional problem caused by holistic variables vis: corruption, ineptitude leadership, neglect of agriculture, weak infrastructure, with negative implication as poverty, low income and insecurity. The study recommends comprehensive approaches which include functional governance, provision of enabling environment and recalibration of policies that will strengthen effective governance, investment and economic growth.
\end{abstract}

Keywords: Unemployment, National Bureau of Statistics, Functional Governance, Investment and Economic Growth. 


\section{Introduction}

It is no longer exaggeration that Nigeria unemployment problem is assuming a worse dimension every day, thereby casting an ominous pall on the entire tapestry of the country. Apart from representing an enormous waste of a country's man power resources, it generates welfare loss in terms of lower output thereby leading to lower income and well-being (Akinboyo, 1987; Raheem, 1993; Fapohunda, 2013; Ibikunle, Orefuwa and Mato, 2019).

However, the recent report released by the National Bureau of Statistics (NBS) is a cause for worrying concern. The NBS report shows that a 20 month interval on the nation's unemployment rate, unemployment rose to $27.1 \%$ in the second quarter of 2020 from $23.1 \%$ recorded in Q3 2018. The NBS in its "Labour force statistics unemployment and underemployment report" noted that unemployment rate among young people $15-34$ years was $34.9 \%$ while underemployment for the same group rose to $28.2 \%$ from $25.7 \%$ in $\mathrm{Q}_{3}$ 2018. The report added, the number of persons in the labour force (people within ages $15-$ 64 who are able and willing to work) was estimated to be $80,291,894$. It was $11.3 \%$ less than the number of persons in $\mathrm{Q}_{3} 2018$ (NBS, 2020; Emefo, 2020).

Furthermore, an appraisal of unemployed youths percentage (in a population of about 200 million) according to worldometer, an online data provider showed an alarming trend as the number exceeds the populations of South African countries. Alarmingly, unemployment (34.9\%) and underemployment $(28.1 \%)$ rates among youths totaled $63 \%$ thus, placing Nigeria, uncomfortably ahead among the worst cases globally. Others in its league are Lasotho (28.2\%), Swaziland (26.5), occupied Palestinian territories (26.4\%) and Mozambique (24.8). In addition, countries with the lowest unemployment rates at the end of 2019 are Qatar (0.1\%), Cambodia (0.3) Niger (0.4\%), Belarus (0.5), Lais (0.7), Myanmar (0.8), Bahran (1.2\%), Tonga (1.2), Thailand (1.4\%), Kuwait (2.0\%), for the world's largest economies, the unemployment levels are Japan (2.4\%), India (3.5\%), Germany (3.6), United Kingdom (3.9\%), United States (4.1\%), China (4.8\%), Canada (5.9) France (8.6\%) and Italy (10.4\%). (http:www.worldometers.infor/demographics/Nigeria-demographics1).

In Nigeria, the National Bureau of Statistics (NBS) indicated that Imo State recorded the highest rate of unemployment with $48.7 \%$ followed by AkwaI-bom and Rivers with $45.2 \%$ and $43.7 \%$ respectively. The report is worrisome as it poses a threat to Imo State development, security and peaceful co-existence. The large number of youths who are unemployed is capable of undermining democratic practice as they constitute a serious threat if engaged by the political class for clandestine activities (Adepegba, 2011; Adebayo, 1999; Ibrahim, 2011; Lartey, 2011; Olatunji and Abionye, 2011; Uddin and Uddin, 2013). However, the critical question is: Does this statistics reflect the true position of Imo State? Is the report a realistic diagnosis? What are the causes, effects, and implication of the unemployment indices on Imolites? Can Imolites successfully and sustainably stem down the future increase? These are critical issues to be examined in the courses of this navigation.

This paper has been divided into the following sections: Introduction, Conceptual Clarifications, Theoretical framework, Unemployment in Imo State, Empirical review, Discussion, Conclusion and Recommendations.

\section{Statement of Problem}

The rate of unemployment in Nigeria is not only alarming but a national embarrassment needing meaningful and tangible action plan. The National Bureau of Statistics reported that 
the Nigeria figure represented an increase of 836,969 persons who were without jobs when compared to $\left(\mathrm{Q}_{3}\right.$ 2018). In fact, Imo State both in terms of unemployment and underemployment has the highest with $48.7 \%$ and $75.1 \%$ respectively. The increase in the unemployment rate is largely attributable to the rising population of potential labour force with other multidimensional variables. Despite the high level of education in Imo state, unemployment challenges continue to manifest. Murk Shrouding the State has plunged many youths into cybercrime, kidnapping, armed robbery, sex slavery, fraudulent acts and depression among others. Also, the increasing rate of poverty and low standard of living may be as a result of high growing unemployment. It is in view of this problem that this study becomes germane to explore the causes, trends and the effects of unemployment in Imo State with a view of finding solution to the gap.

\section{Conceptual Clarifications}

\section{Unemployment}

The International Labour Organization (ILO 2007) defined unemployment as those who are currently not working but willing and able to work for pay, currently available to have and have actively searched for work. In other words, it encompasses the unemployed members of the economically active population, who are without work but available for and those who have voluntarily left their jobs (World Bank, 1999). Adebayo (1999) stated that unemployment exists when members of the labour force wish to work but cannot get jobs.

Fajana, (2000) posited unemployment to a situation where people who are willing and capable of working are unable to find suitable paid employment. Briggs (1993), affirms that unemployment involves the difference between the amount of human resources employed at current wage levels and working conditions, and the amount of human resources not hired at these levels. Equally, Gbosi (2006) averred that unemployment is a situation in which people who are willing to work at the prevailing wage rate are unable to find jobs. Also, National Bureau of Statistics sees unemployment as the proportion of the labour force that is available for work but did not for at least thirty nine (39) hours in the week preceding survey period (NBS, 2020).

Therefore, unemployment arises when persons that are capable, qualified, skilled, ready and willing to work at the ruling wage but cannot get work.

\section{Underemployment}

Underemployment is a measure of employment and labour utilization in the economy that works at how well the labour force is being utilized in terms of skills, experience and availability to work. Indeed, it refers to a situation individuals are forced to work in low paying or low skill jobs. Anyanwuocha (1993) cited in Otu and Okon (2016), argues that labour is said to be underemployed if it is working below capacity or not fully utilized in production. As a macro-economic problem, unemployment could be friction, residual, structural, technological and seasonal in nature. It is frictional when it is caused by industrial friction in which jobs may exist, yet the workers may be unable to fill them either because they do not possess the necessary skill or because they are not aware of the existence of such jobs. Residual unemployment is caused by personal factors such as old age, physical or mental disability, poor work attitude and inadequate training. While technological unemployment is caused by changes in the techniques of production. 
In fact, technological changes are taking place constantly leading to the increased mechanization of the productive process. This naturally results in the displacement of labour, thus causing unemployment (Fajana, 2000: Alao, 2005; Wikipedia, 2010; Uddin and Uddin, 2013; Oladele, Akeke and Oladunjoye, 2011).

\section{Theoretical Framework}

It has become a universal phenomenon in Social and Management Sciences for facts to be investigated or examined precisely within a theory, rather than in an isolated manner. For Goode and Hatt (1952), theoretical orientation functions mainly by bridging the range of facts that are to be investigated. In an empirical theoretical base it is necessary to develop a sound theory which is capable of explaining the use concepts and relationships of variables in the study. The essentiality of theoretical insight in a study is also pigeon-holed in the fact that social research is theory guided by relevant principles of human behavior (Good and Hatt, 1952).

Consequently, this study is anchored on the theory of Neo-liberalism is an attempt to describe the complication of unemployment in Imo State, Nigeria. Neo-Liberalism is a Marxist political economy theory that engages in economic practices. The theory suggests that human well-being could be best achieved through privatization as freedom would be granted to individuals for ownership of property for free market transactions and for rapid development of the society. The theory added that government should concentrate in providing enabling environment for smooth and successful running of the aforesaid.

Thus, provision of infrastructure and security are part of the essentials of the enabling environment as proposed by the theory (Wayas, Selvadurai, Awang, 2019). The main assumption of the theory is the transfer of the national economy leadership from the government to business-oriented persons or individuals to achieve greater efficiency while the government engages in pro business strategies and supervisory measures to attract investment (Osakwe and ph, 2013).

Neo-liberalism as theory has in it an element of modernization with its roots in economic transformation and capitalism. The theory stresses on the value of free market competition. The implication of this is that the man that is involved and being used in economic activities would need to be transformed through a targeted orientation for the desired goals. In simple terms, Neo-liberalism is antithetical to the lobbying of group-rather that individual interests for example, that can be achieved through losing of groups or state intervention that protect national interest via tariffs or subsidies. The theory became a global one due to the advice of John Williamson, that International Monetary Fund (IMF), World Bank and World Trade Organization (WTO) should attach to aims and objectives of neoliberalism as a condition to the financial assistance or loans for economic development to developing States. It therefore, became a governmental principle that is related along with global trade and industry and the growth of financial capitalism (Adedeji, Soyinka, Sunday, 2018; Danjuma, 2012; Ayinde, 2008).

\section{Application of the Theory}

Nigerian government in 1986 adopted Neo-liberalism as an economic policy by introducing Structural Adjustment Programme (SAP). At the ending of 1980s, World Bank instructed Nigeria and other developing States that loan out money to them to rationalize their public and civil service and they did. The result of that for Nigeria was thousands of its 
appointment was terminated as its work force was reduced by $40 \%$. Majority of the people that were affected were young persons and women and the economy was badly affected too as it had workable and energetic people that were disengaged from contributing their quota to the economic development of the country (Okafor, 2011).

Therefore the adoption of Neo-liberalism in Nigeria created urbanization and not industrialization and as a result of this, Nigeria ended up of having a weak economy with massive unemployment (Dietrich and Moller, 2016). Although, scholars and researchers had raised the question: that most nations like Malaysia, USA, China, Asian Tigers adopted Neoliberalism are excelling their respective countries, why then Nigeria case is different?

\section{Methodology}

The study adopted qualitative design as its methodology and applied descriptive nature in the application of this research. The data used was generated from the secondary sources. The secondary and documentary sources include books, journals, periodicals, monographic seminars papers, conference papers, published and unpublished research books, magazines, internet materials. Others are statutory and recognized international organizations like the National Bureau of Statistics (NBS), World Bank, Central Bank of Nigeria (CBN), International Labour Organizations Document 1998, 1999, 2007 and 2013 (ILO) Worldometer online data provider, Imo State websites and web based research on employment among others. Equally, extant literature review was greatly utilized on the subject matter. The secondary data generated were analyzed using content analysis. Content analysis has to do with the rigorous analysis and examination of written records in a critical, analytical, descriptive and explanatory manner so as to make generalization and meaning from such written records and documents.

According to Kerlinger (1977, cited in Ebiziem et al., 2020) content analysis is a research technique for objective, systematic, quantitative and qualitative description of the manifest content of communication. The central objective of content analysis is to convert recorded data or information into data which can be treated in a scientific manner so that a body of knowledge may be built up.

\section{Unemployment in Imo State}

Unemployment has been a reality in Imo State even before the current National Bureau of Statistics (NBS) 2020 alarm was sounded. Imo State has been laboring under economic devastation and recession for a very long time due to poor governance and leadership ineptitude.

Historically, Imo State was created by Decree No 12 of February 3, 1976, since then, the State has witnessed both military and democratic governance. The State covers an area of about $5,100 \mathrm{sqkm}^{2}$, with about 6 million population, endowed with human and natural resources. The natural resources includes: crude oil, natural gas, lead and zinc, iroko, mahogany, obeche, bamboo, rubber tree and oil palm; other natural resources found in the State are white clay, fine sand and limestone among others. Imo State consists of twentyseven Local Government Areas including: Aboh-Mbaise, Ahiazu-Mbaise, Ehime-Mbano, Ezinihitte-Mbaise, Ideato North, Ideato South, Ihitte/Uboma, Ikeduru, Isiala-Mbano, Isu, Mbaitoli, Ngor-Opkala, Njaba, Nkwerre, Nwangele, Obowo, Oguta, Ohaji/Egbema, Okigwe, Onuimo, Orlu, Orsu, Oru-East, Oru-West, Owerri Municipal, Owerri North, Owerri West. Equally, there are over 163 oil wells at over 12 different locations in the State. The main 
petroleum companies operating in the state are Addax Petroleum, Chevron Corporation, Royal Dutch Shell and Agip. Some of the established oil-rich and producing Local Government Councils include Ohaji/Egbema, Oguta, Oru-East, Oru-West, Obowo and NgorOkpala (Otu and Okon, 2016).

Undoubtedly, the Administration of Governor Mbakwe (1979 - 1983), sincerely established Cottage industries one in each Local Government Areas in the State. They include: Adapalm Ltd Ohaji, Avutu Modern Poultry Obowo, Imo Concorde Hotel Owerri, Resin Paint Mbaise, Ezenachi Clay Bricks Okigwe, Standard Shoe at Owerri, Aluminum Extrusion Iyishi, Nsu Tiles Ehime-mbano, Nekede Fisheries, Amaraku Independent Power Plant, Imo Rubber Estate Emeabiam, Imo Airport, Paper Cardboard Owerri Ebeiri among others.

Regrettably, most of these industries became moribund as successive administration failed to consolidated on this great laid industrial foundation. Some of the industries were either leased, privatized or outright sold, on personal interests. In effect, many investors due to the unfavourable business climate including devastation in critical infrastructure like security, roads, electricity and stable polity re-located or folded their firms thereby causing workers to lost their employment and became jobless.

Structurally, the State witnessed both the formal and informal sectors struggle with declining economic activities as a result of the sudden fall in oil price in the world market and subsequent recession and meltdown a development that led to the closure of many industries and few that survived retrenched a large proportion of their work force (Odusola; 2001; Douglason and Gbosi, 2006; Fapohunda, 2003)

Furthermore, Douglason and Gbosi (2006) assert that the SAP adopted in 1986 had serious implication on employment in Nigeria, Imo State inclusive. Unemployment rate declined from $7.1 \%$ in 1987 to $1.8 \%$ in 1995 and covered between 5.6 and $8.4 \%$ between 1996 and 2000 respectively. 
Table 1: Labour Force Statistics, 2020

\begin{tabular}{|c|c|c|c|c|c|c|c|c|c|c|}
\hline & LABOUR & Work & Work & Work & & Total & \multicolumn{3}{|c|}{ UNEMPLOYMENT RATES } & \multirow{2}{*}{$\begin{array}{c}\text { Under } \\
\text { Employmen } \\
\text { Rate }\end{array}$} \\
\hline & & $\begin{array}{c}\text { Fully } \\
\text { Employed }\end{array}$ & $\begin{array}{c}\text { Under- } \\
\text { employed }\end{array}$ & Unemployed & Unemployed & & $\begin{array}{l}\text { OLD } \\
\text { Nigeria }\end{array}$ & $\begin{array}{c}\text { NEW } \\
\text { Nigeria }\end{array}$ & International & \\
\hline Total & 80,291894 & $35,585,274$ & $22,942,003$ & $12,395,364$ & $9,369,253$ & $21,764,617$ & 55.7 & 27.1 & 11.7 & 28.6 \\
\hline ABIA & $1,605,290$ & 475,997 & 558,684 & 344,774 & 225,835 & 570,609 & 70.3 & 35.5 & 14.1 & 34.8 \\
\hline ADAMAWA & $1,789,609$ & 578,421 & 687,469 & 403,915 & 119,803 & 523,719 & 67.7 & 29.3 & 6.7 & 38.4 \\
\hline AKWA-IBOM & $2,534,495$ & 838,995 & 551,101 & 543,238 & 601,161 & $1,144,399$ & 66.9 & 45.2 & 23.7 & 21.7 \\
\hline ANAMBRA & $2,256,435$ & $1,575,934$ & 384,176 & 147,572 & 148,754 & 296,325 & 30.2 & 13.1 & 6.6 & 17 \\
\hline BAUCHI & $2,535,661$ & 890,184 & $1,090,070$ & 441,737 & 113,670 & 555,407 & 64.9 & 21.9 & 4.5 & 43 \\
\hline BAYELSA & $1,033,280$ & 532,775 & 212,834 & 67,883 & 219,788 & 287,671 & 48.4 & 27.8 & 21.3 & 20.6 \\
\hline BENUE & $2,641,049$ & 863,296 & $1,159,815$ & 375,408 & 242,530 & 617.938 & 67.3 & 23.4 & 9.2 & 43.9 \\
\hline BORNO & $1,130,154$ & 532,233 & 373,338 & 133,340 & 91,243 & 224,583 & 52.9 & 19.9 & 8.1 & 33 \\
\hline $\begin{array}{l}\text { CROSS } \\
\text { RIVER }\end{array}$ & $1,959,675$ & 820,596 & 520,595 & 322,902 & 295,583 & 618,484 & 58.1 & 31.6 & 15.1 & 26.6 \\
\hline DELTA & $2,494,452$ & 987,814 & 500,790 & 633,855 & 371,994 & $1,005,848$ & 60.4 & 40.3 & 14.9 & 20.1 \\
\hline EBONYI & $1,337,032$ & 798,050 & 344,114 & 143,026 & 51,842 & 194,868 & 40.3 & 14.6 & 3.9 & 25.7 \\
\hline EDO & $1,985,765$ & 916,871 & 692,160 & 143,506 & 233,228 & 376,734 & 53.8 & 19 & 11.7 & 34.9 \\
\hline EKITI & $1,218,848$ & 741,943 & 288,519 & 101,639 & 86,747 & 188,386 & 39.1 & 15.5 & 7.1 & 23.7 \\
\hline ENUGU & $2,150,839$ & $1,086,328$ & 478,943 & 190,402 & 397,165 & 585.568 & 49.5 & 27.2 & 18.4 & 22.3 \\
\hline GOMBE & $1,330,299$ & 411,643 & 476,178 & 248,746 & 193,733 & 442,478 & 69.1 & 33.3 & 14.6 & 35.8 \\
\hline IMO & $2,484,757$ & 618,481 & 656,394 & 593,347 & 616,535 & $1,290,882$ & 75.1 & 48.7 & 24.8 & 26.4 \\
\hline JIGAWA & $1,979,245$ & 787,814 & 748,937 & 367,753 & 74,742 & 442,495 & 60.2 & 22.4 & 3.8 & 37.8 \\
\hline KADUNA & $3,363,515$ & 915,332 & $1,108,231$ & $1,032,632$ & 307,320 & $1,339,952$ & 72.8 & 39.8 & 9.1 & 32.9 \\
\hline KANO & $4,512,843$ & $1,485,547$ & $1,602,610$ & 800,767 & 623,919 & $1,424,686$ & 67.1 & 31.6 & 13.8 & 35.5 \\
\hline KATSINA & $2,756,710$ & $1,056,408$ & $1,049,620$ & 533,477 & 117,205 & 650,682 & 61.7 & 23.6 & 4.3 & 38.1 \\
\hline KEBBI & $1,527,375$ & 728,960 & 552,718 & 194,100 & 51,596 & 245,697 & 52.3 & 16.1 & 3.4 & 36.2 \\
\hline KOGI & $1,878,990$ & 581,093 & 620,800 & 366,657 & 310,440 & 677,097 & 69.1 & 36 & 16.5 & 33 \\
\hline KWARA & $1,348,737$ & 887,484 & 275,090 & 90,115 & 96,048 & 186,163 & 34.2 & 13.8 & 7.1 & 20.4 \\
\hline NASARAWA & $1,035,256$ & 599.147 & 270,881 & 84,367 & 80.865 & 165,232 & 42.1 & 16 & 7.8 & 26.2 \\
\hline NIGER & $2,093,381$ & 777,391 & 608,432 & 332,973 & 374,585 & 707,559 & 62.9 & 33.8 & 17.9 & 29.1 \\
\hline OGUN & $2,229,187$ & $1,404,531$ & 461,935 & 265,208 & 97,521 & 362,720 & 37 & 16.3 & 4.4 & 20.7 \\
\hline ONDO & $2,085,659$ & 981,264 & 664,006 & 202,592 & 237,797 & 440,389 & 53 & 21.1 & 11.4 & 31.8 \\
\hline OSUN & $1,937,531$ & $1,221,052$ & 420,889 & 268,098 & 27,492 & 295,590 & 37 & 15.3 & 1.4 & 21.7 \\
\hline OYO & $3,174,707$ & $2,078,273$ & 575,218 & 252,651 & 268,565 & 521,216 & 34.5 & 16.4 & 8.5 & 18.1 \\
\hline PLATEAU & $1,832,185$ & 674,460 & 512,559 & 443,059 & 202,107 & 645,166 & 63.2 & 35.2 & 11 & 28 \\
\hline RIVERS & $3,921,860$ & $1,431,697$ & 775,974 & 590,132 & $1,124,057$ & $1,714,189$ & 63.5 & 43.7 & 28.7 & 19.8 \\
\hline SOKOTO & $1,557,378$ & 969,596 & 371,443 & 126,376 & 89,963 & 216,339 & 37.7 & 13.9 & 5.8 & 23.9 \\
\hline TARABA & $1,351,313$ & 457,396 & 361,396 & 454,158 & 78,362 & 532,520 & 66.2 & 39.4 & 5.8 & 26.7 \\
\hline YOBE & $1,115,935$ & 388,947 & 428,427 & 238,209 & 60,354 & 298,563 & 65.1 & 26.8 & 5.4 & 38.4 \\
\hline ZAMFARA & $1,495,490$ & 632,285 & 653,227 & 170,692 & 39,285 & 209,978 & 57.7 & 14 & 2.6 & 43.7 \\
\hline FCT & $1,775,089$ & 859,003 & 400,090 & 287,230 & 228,766 & 515,996 & 51.6 & 29.1 & 12.9 & 22.5 \\
\hline
\end{tabular}

Source: National Bureau of Statistics (NBS), 2020

Table I: Unemployment trends are carefully shown above with high increasing rate of unemployment and underemployment in Imo State as reported by National Bureau of Statistics (NBS, 2020). As indicated on the above figures on this table Imo State has $48.7 \%$ unemployment and $75.1 \%$ underemployment rates respectively from the presented statistics NBS comprehensively captured and illustrate the Labour Force statistics of the thirty six 36 States of Nigeria including the federal capital territory Abuja. A careful analysis of its statistics indicated that unemployment and underemployment is rapidly growing up in Imo State. This could be attributed to many factors including highly skilled labour force and weak governance. 


\section{Causes of Unemployment}

Extant literature (Ibikunle, Orefuwa and Mato, 2019: Wayas, Selvaduvai and Awang, 2019; Uddin and Uddin, 2013; Fapounda, 2013; Out and Okon, 2016; Akintoye 2008) are indeed replete with the fact of the causes of unemployment and its effects in Imo State, Nigeria. The critical factors are:

(i) Neglect of the Agriculture sector: The Agriculture sector employs a greater percentage of the people mostly in the rural areas. The percentage of rural employment in Agriculture today in Imo State is very low and it has affected the people both in terms of food security and employment opportunities. Imo State has fertile areas like Ngor-Okpala, Onuimo, Ohaji Egbema, Ehime-mbano, Ihitte Uboma for good agricultural production, but the abandonment of agriculture to white collar that is not available has aggravated the situation.

(ii) Poor educational planning: In fact, the declining quality of education skills and technical know-how undermines the employability of the labour force. Most of the people with high level of certificates are sufficiently not equipped for the desirable job because they lack the prerequisite for the work in the present-day-dispensation (Otusanya, 2011). In other words, the education acquisition skills that furnish the youth with the preferred skills for self-reliance to enable them contribute immensely to themselves and the countries are important and imperative (Adesina, 2013).

(iii) Weak supporting Environment: It has been observed that the poor nature of power supply, good road network, pipe borne water and other vital infrastructures that are needed for industrial growth and investment were among the factors that created unemployment problems in the State. Therefore, the poor enabling environment has continued to pose serious challenges to employment generation in Imo State.

(iv) Corruption: Corruption which is unlawful behavior and misappropriation of public resources has continued to dominate the governance of the State. The regimes that ruled the State apart from that of Mbakwe had diverted the public goods and resources to their personal needs thereby deprived the State the developmental strides that could have created employment opportunities to the youths. In fact embezzlement, tax avoidance and tax averting, falsification of records, stealing, dishonest and fraudulent practices continued to prevail in the public service.

(v) Security Challenges: The security challenges in the country are a major problem accountable for unemployment among the youths. The activities of Boko Haram, Fulani herdsmen, militants, separative agitators, like IPOB, Massob, kidnappers terrorist continued to affect business climate as investors and industrialist flew for their safety forcing the closure of their companies and factories and the employees became jobless and it increased unemployment ratio (Edojpolor and Owenvbibgic, 2017)

Furthermore, other factors include the limited access to credit facilities to enterprises, which could have strengthened their operational viability and functionality, policy inconsistency or somersault; lack of visionary leadership to champion sound socio-economic policy among others. 
Article DOI: 10.46654/ij.24889849.s61016

Table 2: Imo State Population Distribution

\begin{tabular}{|c|c|c|c|c|}
\hline Name & Status & $\begin{array}{l}\text { Population Census } \\
\text { 1999-11-26 }\end{array}$ & $\begin{array}{l}\text { Population Census } \\
\text { 2006-03-21 }\end{array}$ & $\begin{array}{l}\text { Population Projection } \\
\text { 2016-03-21 }\end{array}$ \\
\hline Imo & State & $2,485,635$ & 3,927563 & $5,408,800$ \\
\hline Aboh-Mbaise & L.G.A & 115,360 & 194,779 & 268,200 \\
\hline Ahiazu-Mbaise & L.G.A & 96,170 & 170,824 & 235,200 \\
\hline Ehime-Mbano & L.G.A & 97,145 & 130,575 & 179,800 \\
\hline Ezinihitte & L.G.A & 92,462 & 168,767 & 232,400 \\
\hline Ideato North & L.G.A & 118,519 & 156,161 & 215,100 \\
\hline Ideato South & L.G.A & 79,236 & 159,654 & 219,900 \\
\hline Ihitte/Uboma & L.G.A & 69,009 & 119,419 & 164,500 \\
\hline Ikeduru & L.G.A & 108,367 & 149,737 & 206,200 \\
\hline Isiala-Mbano & L.G.A & 106,170 & 197,921 & 272,600 \\
\hline Isu & L.G.A & - & 164,328 & 226,300 \\
\hline Mbaitoli & L.G.A & 148,531 & 237,474 & 327,000 \\
\hline Ngor-Okpala & L.G.A & 135,711 & 157,858 & 217,400 \\
\hline Njaba & L.G.A & - & 143,485 & 197,600 \\
\hline Nkwerre & L.G.A & - & 80,270 & 110,500 \\
\hline Nwangele & L.G.A & - & 127,691 & 175,800 \\
\hline Obowo & L.G.A & 64,277 & 117,432 & 161,700 \\
\hline Oguta & L.G.A & - & 142,340 & 196,000 \\
\hline Ohaji/Egbema & L.G.A & 119,116 & 182,891 & 251,900 \\
\hline Okigwe & L.G.A & - & 132,701 & 182,700 \\
\hline Orlu & L.G.A & 117,343 & 142,792 & 196,600 \\
\hline Orsu & L.G.A & 87,521 & 120,224 & 165,000 \\
\hline Oru-East & L.G.A & - & 111,743 & 153,900 \\
\hline Oru-West & L.G.A & - & 115,704 & 159,300 \\
\hline Owerri Municipal & L.G.A & - & 125,337 & 172,600 \\
\hline Owerri North & L.G.A & - & 176,334 & 242,800 \\
\hline Owerri West & L.G.A & - & 101,754 & 140,100 \\
\hline Onuimo & L.G.A & - & 99,368 & 136,800 \\
\hline Nigeria & Federal Republic & $88,992,220$ & 140,431790 & $193,392,500$ \\
\hline
\end{tabular}

Source: National Population Commission of Nigeria (web), National Bureau of Statistics (web)

Table II above shows Imo State population distribution from National Population Commission web. It captures the names of Local Government Areas, status, population census and population projection. The population distribution shows 2,485,635 in (1999), 3,927563 in (2006) and 5,408,800 in (2016). The statistics illustrated increase in the population of the State which also implies that the skilled and qualified workforce will correspondingly increase.

Table 3: Demographic Distribution of Imo State Population

\begin{tabular}{|l|l|}
\hline \multicolumn{2}{|l|}{ Gender (C 2006) } \\
\hline Males & $1,976,471$ \\
\hline Females & $1,951,092$ \\
\hline Age Groups $($ C 2006) \\
\hline 0 -14 years & $1,415,929$ \\
\hline 15 -64 years & $2,341,565$ \\
\hline 65+ years & 170,069 \\
\hline
\end{tabular}




\begin{tabular}{|c|c|}
\hline \multicolumn{2}{|c|}{ Age Distribution (C 2006) } \\
\hline $0-9$ years & 942,457 \\
\hline $10-19$ years & 939,913 \\
\hline $20-29$ years & 730,624 \\
\hline $30-39$ years & 473,193 \\
\hline $\begin{array}{ll}40 & -49 \\
\text { years } & \end{array}$ & 362,409 \\
\hline $\begin{array}{ll}50 & -59 \\
\text { years } & \end{array}$ & 223,726 \\
\hline $\begin{array}{ll}60 & -69 \\
\text { years } & \end{array}$ & 134,392 \\
\hline $\begin{array}{ll}70 & -79 \\
\text { years } & \end{array}$ & 72,937 \\
\hline $80+$ years & 47,912 \\
\hline
\end{tabular}

Source: National Population Commission of Nigeria (web), National Bureau of Statistics (web)

Table III as indicated on the above figures on this table which is demographic distribution of Imo State population as at 2006. The age groups distribution has the following statistics $0-4$ years 1,415,929, $15-64$ years 2,341,565, 65+ years 170,069. Undoubtedly, the statistical figures show that over $50 \%$ of the potential labour force falls within the age brackets of the youths who dominate the mainstream society with the best of their skills and talents the deteriorated nature of infrastructure and closure of industries, unemployment become pronounced in the State.

\section{Empirical Review}

Otu and Okon (2016) investigated the influence of unemployment and underemployment on Economic Development in Imo State Nigeria. The study made use of Ex-post facto research design. Data was generated using a well validated structured questionnaire. Data was analyzed using a linear regression statistical technique. Findings revealed that there is a significant influence of unemployment and underemployment on the level of poverty in Imo State. Also, unemployment significantly influences the level of political and economic insecurity in Imo State. The study recommended that the government should formulate effective unemployment policy which will absorb the unemployed citizens. This study is in line with the present study in terms of addressing the challenges of employment in Imo State.

Ibikunle et al. (2019) carried out an analysis of the causes and effect of unemployment in Nigeria towards a solution for graduate idleness and poverty alleviation. The study made use of secondary data which was gathered from CBN report, NBS report covering the period 
of $1985-2015$. The study employed the regression analysis as the analytical method. The study showed that there is positive relationship between gross capital formation and unemployment rate in Nigeria. It recommended that development of entrepreneurial skills and initiatives through entrepreneurship education and training should be paramount importance especially in the higher education sector so as to facilitate the employability and creativity and productivity of graduates who will derivatively contribute to the wealth of nation not only as job seekers but also as job creators.

Wayas et al. (2019) examined the cause of unemployment among youths in Nigeria. The main objective of the study was to examine causes of unemployment in Nigeria. Secondary sources were used as data for the study with neo-liberal theory as theoretical framework. The result of the study revealed that youth unemployment was mainly caused by corruption among the public office holder that had led to the degrading nature of infrastructures, security and neglect of agriculture. The study recommended self-reliance through vocational and technical courses and enabling environment for business activities among others.

Fapohunda (2013) investigated Reducing Unemployment through the Informal Sector in Nigeria. The objective was to examine the role of the informal sector to promote employment, productivity and income. The study made use of the secondary sources for its data collection. Also, content analysis was fully utilized in its analysis. The paper posits that unemployment in the country can be reduced significantly by expanding the activities of the informal sector. Thus, the informal sector has shown some dynamism in creating new jobs.

Uddin and Uddin (2013) studied Causes, Effects and Solution to youth Unemployment Problems in Nigeria. The objective was to look into the causes, effects and solutions to youth unemployment problems in Nigeria. The data for the study was collected from secondary sources using descriptive approach of previous researchers and analysis of scholars to gather empirical data. The finding revealed unemployment in Nigeria are caused by six major problems and six major effects which have created tension and hatred between haves and have not leading to poverty and constituting hiccups to security of lives and properties. The study recommended that government should create labour market that work better for youths, and government should invest heavily on education to enable youths become self-reliant instead of job seekers through skills development and training.

Also, Oloruntoba and Akinfolarin (2018) carried a study on Reducing Unemployment in Nigeria: An Evaluation of the Entrepreneurship Programmes in Ondo State. Descriptive survey research design was adopted for the study with a total population of five hundred (500) respondents. Data collected on the study were analyzed using frequency count, percentage and mean. The findings of the study revealed among others that respondents were aware of the government and nongovernmental entrepreneurship programmes for poverty reduction. Government should assist in improving the infrastructure deficits in the country especially that of power supply.

\section{Effects of Unemployment}

Fundamentally, unemployment in Imo State has effects both on the individual unemployed, the government society and the entire economy of the State. Admittedly, unemployment has affected the entire Imolites and the economy with social effects of hardship, depression, decay of acquired but unused skills, involvement in crimes such as 
robbery, kidnapping, rape and cultism, marital disputes, delayed marriages among singles and sometimes broken homes. Indeed, it increases poverty inequality and total decline in quality of life among others. Equally, the economic cost of unemployment includes reduction in the State gap and loss of output and income (Bello, 2003; Njoku and Ihugba, 2011; Fadayomi; 1992; Morphy, 2008).

Also, the phenomenon of unemployment effects in Imo State has brough tImolites walking daily along the street with low resourcefulness, idleness to crimes and criminality with sporadic surges of societal unrest (Okoroji, 2019; https://thenigerianvoice.com/news/26334/imo_youths_unemployment).

\section{Discussion}

Based on the records from secondary sources and extant literature reviewed as shown through methodology of this study, some of the causes of unemployment in Imo State were fully discussed, a careful discussion of the statistics indicated unemployment in Imo State was growing rapidly. This corroborates with the study of Wayas et al. (2019) that carried out an examination of the causes of unemployment among youths in Nigeria in which they relied their investigation on NBS unemployment rate by States in Nigeria 2004 - 2011. In that report Imo State was also identified as among States with high level of unemployment.

Similarly, the findings observed chains of factors such as ineptitude leadership, neglect of agriculture, insecurity, corruption, misguided educational qualification and lack of enabling environment. This view is in line with the works of Otu and Okon (2016), who investigates the influence of unemployment and underemployment on economic development in Imo State. Also, the findings of the works of Uddin and Uddin (2013) identified problems and effects as in line with the present study.

Again, the findings of this study is similar to the findings of Oloruntoba and Akinfolarin (2018), who observed that entrepreneurship programmes and skills acquisition are very vital in the reduction of unemployment.

\section{Conclusion}

This empirical study has demonstrated that unemployment is a serious barrier and impediment to the growth of an individual, government, and the entire society. It therefore demands a holistic consideration in addressing its causes and effects. This study posits that unemployment can be reduced significantly through multidimensional approaches of proactive collaboration, integration, good governance, linkages among small and medium scale industries, employment generation and job creation strategies. Indeed, the formulation and effective implementation of the above measures will immensely reduce unemployment in Imo State, Nigeria.

\section{Recommendations}

(1) Promoting and involving a highly functional qualitative technology and science driven education system focused on skills acquisition, innovation, manpower development and entrepreneurship. The system will produce a new generation of graduates equipped for immediate post school employment and self-reliance. Equally, development of a new curriculum for schools that would integrate skills, learning, innovation and entrepreneurship required to fit into the new digital operation. 
(2) Since economic participation in the rural areas is low, agriculture should be fully given a priority by the government and the informal sector, since it creates job employment. The creation of farm settlements in food basket areas such as Ngor-Okpala, Onuimo, IhitteUboma, Ehime-Mbano, Ohaji/Egbema will marginally create employment and increase food production. Similarly, with the establishment of the Ada palm oil mill production, other ancillary companies such as soap making, vegetable oil firm, detergent and cream producing companies can be established from it. These industries when established will employ people and reduce unemployment rates.

(3) Empirical studies and evidence indicate that the private investment has a significant effect on the economic growth than the government because it is more efficient and perhaps less closely associated with corruption (Tairu, 2003). Therefore, the improvement in infrastructure will stimulate the cottage, small and medium scale industries. The infrastructures like Roads, power generation, pipe borne water, adequate security and good taxation will stimulate investment. 


\section{References}

Adebayo, A. (1999). Youth Unemployment and National Directorate of Employment Self Employment Programmes. Nigerian Journal of Economics and Social Studies. 41(1), pp. $81-102$

Adedeji, D. B; Soyinka, K. A; Sunday, O. M (2014). Corruption Control in the Public Sector and the Nigerian Accountant. Int, J. Acad. Res. Accounting, Finance Management Science, (8):1, pp. $91-103$.

Adesina, O. S. (2013) Unemployment and Security Challenges in Nigeria. International Journal of Humanity Social Science, 3(7), PP. 146 - 156.

Akintoye, R. I. (2006). Enhancing the Performance of the Informal Sector for the Economic Development of Nigeria: A Case Study of Lagos State. International Journal of Social Sciences, 5(1), pp. $100-112$.

Akintoye, R. I. (2008). Reducing Unemployment through the Informal Sector: A Case Study of Nigeria, European Journal of Economics, France and Administrative Science ISSN 14502275 , Issue 11.

Alao, O. (2005). Principles of Economics: Macro Darkol Press and Publishers, Isolo, Lagos.

Ayinde, O. E. (2008). Emprical Analysis of Agricultural Growth and Unemployment in Nigeria. African Journal of Agricultural Research, 3(7), pp. 465 - 468. The Global Transformations Reader; an Introduction to the Globalization Debate, Edited by David Held and Anthony McGrew.

Bello, T. (2003). Attacking Unemployment Hurdles in the Fragile Economies of the SubSahara Africa: the Experience of Nigeria. A Paper Presented at the-Economics For the Future-conference; On the Occasion of the Celebration of 100 years of Cambridge Economics; UK: Cambridge.

Briggs, J. E. (1993). Unemployment Statistics and What they Mean. Monthly Labour Bulletin, Vol. 5, Pp. 14.

Danjuma, A. (2012). Good Governance as Panacea to Socio-Economic Crises in Nigeria. IOSR Journal of Business and Management, Vol. 2/3, pp 36 - 40. Accessed from www.iosrjournals.org on 10/10/2020.

Dietrich, H. Moller, J. (2016) Youth Unemployment in Europe-Business Cycle and Institutional Effect. International Economics and Economic Policy, 13 (1), pp. 5 - 25.

Douglason, G. U. and Gbosi, A. (2006). The Dynamics of Productivity and Unemployment in Nigeria, $1^{\text {st }}$ Edition; University Press Ibadan, Dp Publication.

Ebiziem, J. E.; Amadi, j. c, Izim, O. D. Nwimo K. U. (2020). Disturbing Trends in World Trade Organization (WTO: Mobilizing the Member Nations for the Re-building Process. International Journal of Advanced Academic Research (Social and Management Sciences) ISSN:2488 - 9849, 6(8), pp. 1 - 16. Accessed from www.ijaar.org on 10/10/2020. 
Edokpolor, J. E and Owenvbiugie, R. O (2017) Technical and Vocational Education Training Skills: An Antidote for Jobs Creation and Sustainable Development of Nigerian Economy Problem. Education $21^{\text {st }}$ Century 75(6), pp. $535-549$.

Emeto, J. (2020). 21.77 Nigerian now Jobless as Unemployment Rates Rises to $27.1 \%$. ThisDayNewpaper, Saturday 15 August, 2020 Vol. 25, No 9259.

Fadayomi, T. O. (1992). Migration Development and Urban Policies in Sub-Sahara Africa. Ibadan: Codesria Book Series

Fajana, S. (2000). Functioning of the Nigerian Labour Market, Labonfin and Company, Lagos.

Fapohunda, T. M. (2003). Human Resource Planning in Nigeria: The National Directorate of Employment and Unemployment. The Nigerian Journal of Industrial Education and Labour Relations, Vol. 6. No 1\&2. 2003167 -180 University of Ibadan. Ibadan

Fapohunda, T. M. (2013). Reducing Unemployment through the Informal Sector in Nigeria. International Journal of Management Sciences 1 (7), pp. 232 - 244. Accessed from https://www.rasswes.com on 10/10/2020.

Federal Office of Statistics (2006). Nigerian Statistical Fact Sheets on Economic and Social Development. FOS, Nigeria.

Goode, W. J. and Hart. P. K. (1952). Methods in Social Research. New York: McGraw Hill. http://www.worldometers.info/demographic/nigeria-demographics/. Accessed on 10/10/2020. https:// Vision 2020.co20/11startegies_to_reduceunemployment. Accessed on 10/10/2020.

Ibikunle, G. A, Orefuwa, E. R, Mato, A. B. (2019). Analysis of the Causes and Effects of Unemployment in Nigeria Towards a Solution for Graduate Idleness and Poverty Alleviation. Journal of Humanity and Social Science (IOSR - JTTSS), (24) 2 PP. 36 44. Accessed from www.iosrjournals.org on 10/10/2020.

International Labour Organization (1998). World Employment. Accessed from www.ilo.org/public/english bureau/inf/pkits on 10/10/2020

International Labour Organization (1999). World Employment. Accessed from www.ilo.org/public/english bureau/inf/pkits on 10/10/2020.

International Labour Organization (2013). World Employment. Accessed from www.ilo.org/public/english bureau/inf/pkits on 10/10/2020.

International Labour Organization (2007). Enterprises Based Youths Employment Policies, Strategies and Programmes Initiatives for the development of Enterprise Action and Strategies, ILO Skills Working Paper No. 1. Incorporation U.S.A.

Mbakwe, S. O. (1999), Imo State Industrial Development 1979 - 1983. Accessed from https://www.google.comls on 10/10/2020.

Morphy, R. (2008). Nigerian: Youth Unemployment, Poverty - a Time Bomb for Country. Leadership, Wednesday, 27 August National Bureau of Statistics Annual SocioEconomic

Reported.

Accessed

from 
http/www.nigerianstatgovng/uploads/latestreleaseff063b27de8aa15b35f1a6fb04bf472c 658d939.pdf(2011) on 10/10/2020

National Bureau of Statistics (2010). Statistical News: Labor Force Statistics No. 476. Abuja: The NBS National Population Commission and ICF Macro. (2009). Nigeria Demographic and Health Survey 2008. Abuja: National Population Commission and ICF Macro.

National Bureau of Statistics (2020) Unemployment and Underemployment Report. Accessed from www.nigerianstat.gov.ng on 10/10/2020.

Nigerian National Bureau of Statistics Review of the Nigerian Economy 1997, Lagos, 4(2), pp. 36.

Njoku, A. and Ihugba, O. A. (2011). Unemployment and Nigerian Economic Growth (19852009). Proceeding of the 2011 International Conference on Teaching, Learning and Change. International Association Forteaching and learning (IATEL).

Odusola(2002), Odusola, A. F. (2001). Nigeria's Unemployment Problem in the 80s and 90s: Implication for Self Reliance, $1^{\text {st }}$ Edition; University of Ibadan Press Publication.

Okafor, E. (2011). Youth Unemployment and Implications for Stability of Democracy in Nigeria. Journal of Sustainable Development, 13(1), pp. 358 - 373.

Okoroji, S. U. (2019) Imo Youths Unemployment the Need for Industrialists Come 2019. Accessed from https://thenigerianvoice.com/news/263441/imo_youths_unemployment_the)need_of_i ndustrialists_come20.html. On 10/10/2020.

Olalokun, T. Y. (2002). Globalization and Employment Generation, Evaluation Policy Directions in the $21^{\text {st }}$ Century. NCEMA Policy Seminal Series. Ibadan, Nigeria

Oloruntoba, J. M. Akinfolarin, A. V. (2018). Reducing Unemployment in Nigeria: An Evaluation of the Entrepreneurship Programmes in Ondo State. Journal for Studies in Management and Planning, 4 (1), pp. 26 - 36. Accessed from https://edupediapublications.org/journals/index.php/JSMAP/ on/10/10/2020.

Osakwe, C. and Ph. (2013). Youth Unemployment and National Security in Nigeria Department of History and International Studies. International Journal of Humanities and social Science, 3(12), pp. $258-263$.

Otu, C. A. and Okon, A. N. (2016) Unemployment and underemployment on Economic Development in Imo State, Nigeria: Effects and Defects. Journal of Economics and Finance IOSR - JEF e-ISSN:2321-5933, p-ISSN:2321 - 5925, 7 (6), Pp. 01 - 08.

Otusanya, O. J. (2011). The Role of Multinational Companies in Tax evasion and tax Avoidance: The Case of Nigeria. CritPerspective Account, 22(3), Pp. 316 - 332.

Tairu, B. (2003). Attacking Unemployment Hurdles in the Fragile Economies of the SubSaharan African: The Experience of Nigeria. College of Foreign Affair Students' Education, China.

The Guide Newspaper Editorial, Sept, 20 (2020). The Crisis of Nigeria's Worsening Unemployment Rate Page 2. 
Uddin, P. S. O., Uddin, O. O (2013). Causes, Effect and Solution to Youth Unemployment Problems in Nigeria. Journal of Emerging Trends in Economics and Management Sciences (JETEMS), 4(4), PP. 397 - 402. Accessed from jetems.scholarlinkresearch.org on 10/10/2020.

Wayas, G. G. Selvadurai, S. Awang, A. H. (2019). An Examination of the Causes of Unemployment among Youth in Nigeria. International Journal of Innovative Technology and Exploring Engineering (IJITEE) ISSN:2278 - 3075, (8), 122. 